\title{
Wolbachia infection and parasitoid occurrence among plant-feeding caterpillars of the endangered butterfly Phengaris teleius (Lepidoptera: Lycaenidae) in southern Poland
}

\author{
Ewa B. Śliwińska, Rafał Martyka, Mariusz Cichoń \& Piotr Tryjanowski
}

\begin{abstract}
Śliwińska, E. B., Martyka, R., Cichoń, M. \& Tryjanowski, P. 2019: Wolbachia infection and parasitoid occurrence among plant-feeding caterpillars of the endangered butterfly Phengaris teleius (Lepidoptera: Lycaenidae) in southern Poland. — Entomol. Fennica 30: 20-27. https://doi.org/10.33338/ef.79902
\end{abstract}

Parasites are an important component of ecological communities, as they shape host population dynamics and interfere with interspecific competition in ecosystems. Here, we studied Wolbachia infection and parasitoid occurrence among caterpillars of the endangered Phengaris teleius butterfly in five populations inhabiting southern Poland. The knowledge about potential parasites of $P$. teleius may be of particular importance for understanding forces regulating population processes of this species. Our study showed lack of Wolbachia infection and endoparasitoids in the sample of $914^{\text {th }}$ instar P. teleius caterpillars. However, we found larvae of an unidentified hymenopteran ectoparasitoid on $173^{\text {rd }}$ and $4^{\text {th }}$ instar $P$. teleius caterpillars. We compare our results to findings from other populations of $P$. teleius, and its sister species in Europe and Asia, and discuss possible causes of observed patterns of parasite occurrence.

E. B. Śliwińska \& R. Martyka, Institute of Nature Conservation, Polish Academy of Sciences, Mickiewicza 33, 31-120 Kraków, Poland; E-mails: sliwinska @iop.krakow.pl,martyka@iop.krakow.pl

M. Cichoń, Institute of Environmental Sciences, Jagiellonian University, Gronostajowa 7,30-387 Kraków,Poland; E-mail: mariusz.cichon@uj.edu.pl P. Tryjanowski, Institute of Zoology, Poznań University of Life Sciences, Wojska Polskiego 71C,60-625 Poznań, Poland; E-mail:piotr.tryjanowski@gmail.com

Received 16 October 2017, accepted 14 May 2018

\section{Introduction}

Wolbachia (Hertig \& Wolbach, 1924) (Rickettsiales: Rickettsiaceae) is a bacterial parasite of invertebrate animals that causes several problems, particularly in the conservation management of Lepidoptera (Hamm et al. 2014). Wolbachia is an intracellular $\alpha$-proteobacterium that has the ability to manipulate the biology of its invertebrate hosts. In Lepidoptera, Wolbachia infection may induce feminization of genetic males, kill the male progeny of infected females and cause cytoplasmic incompatibility (i.e. inability of infected males to successfully mate with females lacking the same Wolbachia strain; Werren et al. 2008). Typically, Wolbachia spreads vertically in populations and is inherited maternally due to its presence in the cytoplasm of female gametes (Werren et al. 2008). The presence of Wolbachia may decrease the effective population size of Lepidop- 
Fig. 1. Map of the study area with locations of the sampled Phengaris teleius populations (black dots). Localities: 1 -Kraków-Kostrze, 2 - Barczków, 3 - Jadowniki Mokre, 4 - Żukowice Stare, 5 Zaczarnie.

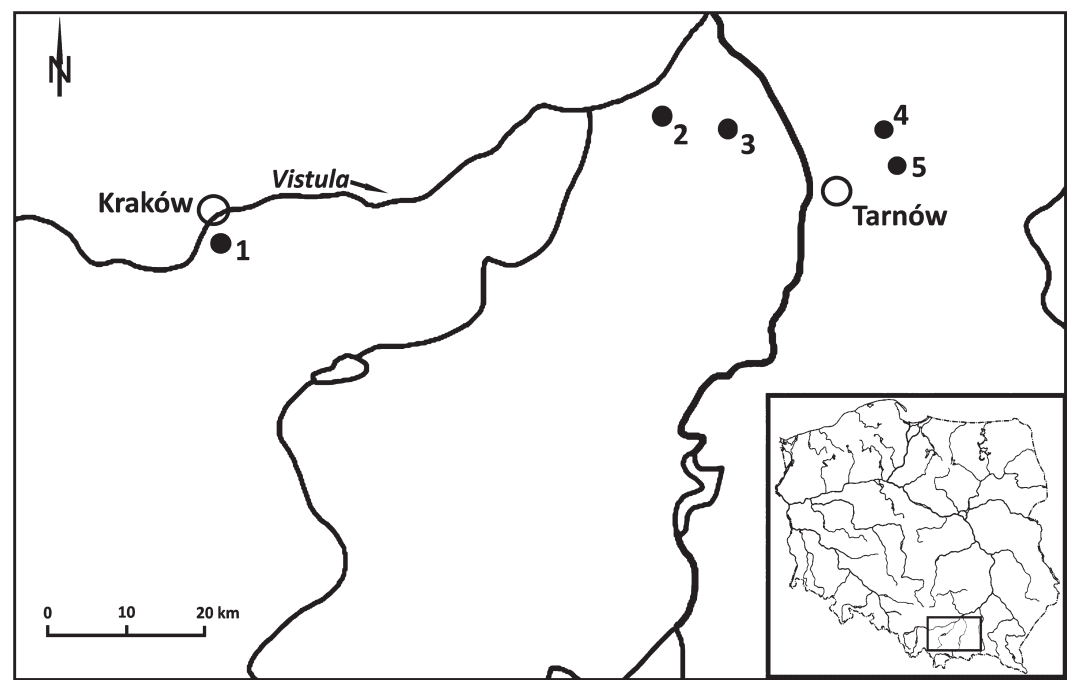

tera and therefore poses a serious risk for threatened butterfly species (Hamm et al. 2014).

Parasitoid wasps (from the suborder Apocrita) are an example of parasites specialized in utilizing different arthropod species, including butterflies (Hinz 1983, Goulet \& Huber 1993, Quicke 1997). Adult parasitoids attack Lepidoptera as eggs, larvae or pupae, laying their eggs inside the insects (endoparasitoids) or on their cuticulae (ectoparasitoids). Parasitoids can be used in pest control (e.g. van Lenteren \& Woets 1988, van Lenteren 2000), but may negatively influence endangered populations of their hosts, as even a few dozen parasitoid species may attack the same host species (Godfray \& Charles 1994).

In this study, we assessed the occurrence of Wolbachia infection among caterpillars of the scarce large blue butterfly Phengaris teleius (Bergsträsser, 1779), originating from populations located in southern Poland. In the course of sampling, we also recorded the presence of parasitoid larvae on $P$. teleius caterpillars. Phenagris teleius is a threatened butterfly (van Swaay \& Warren 1999, van Swaay et al. 2012) that is considered to be a flagship species for nature conservation in Europe (Thomas 1995, Thomas \& Settele 2004).

Identifying the potential parasites of $P$. teleius may be important for understanding population processes in this species (Dobson \& Hudson 1986), with potential significance for conservation management of the butterfly (e.g. McCallum
\& Dobson 1995, Shaw \& Hochberg 2002, Hamm et al. 2014).

\section{Materials and methods}

\subsection{Study species, site and general procedures}

The $P$. teleius butterfly is characterized by a complicated life cycle. Its caterpillar is a monophagous herbivore that feeds exclusively on the great burnet Sanguisorba officinalis L. As a $1^{\text {st }}$ to $3^{\text {rd }}$ instar caterpillar, it feeds inside a single flower bud until leaving the plant (Thomas 1984). $4^{\text {th }}$ instar larvae drop to the ground, remaining there to wait for foraging Myrmica Latreille, 1804 ants. If foraging worker ants come across such a caterpillar, they take it to their ant colony in a process called adoption (Thomas 1984). The predatory $P$. teleius caterpillar then spends 11 or 23 months in the Myrmica nest, feeding on the ant brood (Thomas 1995, Witek et al. 2006). It pupates in late spring/early summer and leaves the colony as an adult butterfly between June and August (Thomas 1995, Witek et al. 2006).

We searched for Wolbachia infection and recorded parasitoid presence among caterpillars originating from five separate $P$. teleius populations in the western part of the Sandomierz Basin, southern Poland, in the years 2013-2014 (Fig. 1). In both seasons, the study was conducted in $\mathrm{Au}-$ 
Table 1. Data gathered from five populations during two years of study, including number of inspected food plants, total number of caterpillars and number of caterpillars with ectoparasitoid larvae.

\begin{tabular}{|c|c|c|c|c|}
\hline \multirow[b]{2}{*}{ Year } & \multirow[b]{2}{*}{ Population } & \multirow[b]{2}{*}{$\begin{array}{l}\text { No. of plants } \\
\text { inspected }\end{array}$} & \multicolumn{2}{|c|}{ No. of caterpillars } \\
\hline & & & collected & $\begin{array}{l}\text { with ecto- } \\
\text { parasitoid } \\
\text { larva }\end{array}$ \\
\hline \multirow[t]{3}{*}{2013} & Barczków & 60 & 56 & 3 \\
\hline & Jadowniki Mokre & 80 & 118 & 3 \\
\hline & Żukowice Stare & 30 & 102 & 9 \\
\hline \multirow{5}{*}{2014} & Barczków & 60 & 194 & 1 \\
\hline & Jadowniki Mokre & 40 & 104 & 0 \\
\hline & Żukowice Stare & 26 & 60 & 0 \\
\hline & Zaczarnie & 22 & 26 & 0 \\
\hline & Kraków-Kostrze & 43 & 118 & 1 \\
\hline
\end{tabular}

gust when caterpillars, in their $4^{\text {th }}$ larval instar, are most likely to be found on food plants. In each population, we randomly gathered a set of food plants that were later inspected under laboratory conditions to find $P$. teleius caterpillars.

After detecting a caterpillar, we confirmed its species and determined its larval instar, based on the identification table in Śliwińska et al. (2006), using a Nikon microscope SMZ 1500 (magnification 10-20×). In total, we found and investigated 778 P. teleius caterpillars at different larval instars, from 361 food plant stems (for details see Table 1). Afterwards, to kill and preserve the caterpillars, they were submerged in a solution of RNA Later $(20 \mathrm{mM}$ sodium citrate, $10 \mathrm{mM}$ EDTA, 70\% ammonium sulphate, pH 5.2; RNA Later solution also stabilizes DNA) and frozen at $-30{ }^{\circ} \mathrm{C}$ until further examination.

To determine the presence of Wolbachia infection, we examined $4^{\text {th }}$ instar caterpillars (91 caterpillars in total). As Wolbachia was not detected in $4^{\text {th }}$ instar caterpillars (see below), we did not find it necessary to include younger larvae in our sample.

\subsection{Molecular determination of Wolbachia infection}

To test for Wolbachia infection in $P$. teleius caterpillars, we performed PCR of the $16 \mathrm{~S}$ rDNA frag- ment using PCR protocols available in Patricelli et al. (2013) and W-Specf and W-Specr primers from Werren and Windsor (2000). Additionally, we used universal arthropod primers for $28 \mathrm{~S}$ rDNA (as in Nice et al. 2009) to verify the negative results of the 16S rDNA Wolbachia PCR. For each sample, one or two PCRs were then performed. First, all samples were screened for Wolbachia (16S rDNA PCR) and afterwards, the samples with a negative result were analysed for arthropod 28S rDNA to check for overall PCR quality. In cases where the quality of $28 \mathrm{~S}$ rDNA PCR was poor, the DNA sample was sequentially diluted, following Nice et al. (2009), and Wolbachia PCR was performed again to confirm the negative result. DNA isolation was performed as follows. A whole caterpillar body was macerated in $50 \mu 1$ of TE buffer, and $1 \mu 1$ of Proteinase K (Thermo Scientific, 14-22 mg/ml) was added. The mixture was then placed in a thermoblock for $2 \mathrm{~h}$ at $56^{\circ} \mathrm{C}$. After protein digestion, $100 \mu 1$ of $5 \%$ CHELEX (chelating material, BioRad) solution was added and the mixture was intensively vortexed for $1 \mathrm{~min}$. After that, the mixture was placed in a thermoblock at $95{ }^{\circ} \mathrm{C}$ with an intensive shake $(1,400 \mathrm{rpm})$ for $10 \mathrm{~min}$ and then centrifuged at 13,000 rpm for $10 \mathrm{~min}$. The supernatant with purified DNA was taken to the PCR chamber. PCR was performed in a SensoQuest Labcycler. The PCR products were visualized on $1 \%$ agarose gels. 


\subsection{Inspection for parasitoids}

At the moment of extraction from inflorescences, each caterpillar, from $1^{\text {st }}$ to $4^{\text {th }}$ instars, was inspected for ectoparasitoid larvae feeding on the surface of their bodies. Furthermore, all $4^{\text {th }}$ instar $P$. teleius caterpillars were checked for the presence of endoparasitoid larvae. We examined only $4^{\text {th }}$ instar caterpillars, as visual detection of younger endoparasitoids is unreliable in P. teleius (Anton et al. 2007b, Anton, personal inform.). Thus, each $4^{\text {th }}$ instar caterpillar was dissected, after thawing under sterile conditions (on a singleuse microscope slide, cut with a single-use sterile scalpel and sterile microscope needle), in order to find the parasitoid larvae inside the body using a Nikon microscope SMZ 1500 (magnification 10 $20 \times)$. After inspection, the caterpillar was again placed in RNA Later solution for further genetic analyses of Wolbachia infection.

\section{Results}

All $4^{\text {th }}$ instar caterpillars of $P$. teleius were found to be free from Wolbachia infection. In addition, no endoparasitoids were found in our sample, either. In contrast, we detected larvae of ectoparasitoid wasps that, however, remained unidentified. We were unable to rear the parasitoids to the adult stage, and any attempts to assign the larvae, even to a family on morphological grounds, would have remained uncertain (Burks 2003). Unfortunately, we also lost the genetic material of the ectoparasitoid larvae, due to difficulties associated with preservation of DNA samples, so that DNA barcoding could not be applied either. Infested caterpillars were paralyzed, i.e. all muscles of a caterpillar were loosened, and it did not move, although it remained alive during the observation (Fig. 2). In total, we found 17 caterpillars ( $3^{\text {rd }}$ and $4^{\text {th }}$ instars) with ectoparasitoid larvae, in the four studied P. teleius populations (for details see Table 1).

\section{Discussion}

In our study, we found no Wolbachia infection among the screened $P$. teleius caterpillars origi- nating from five studied populations, located in the western part of the Sandomierz Basin, in southern Poland. The lack of Wolbachia infection was confirmed by the most appropriate and sensitive available molecular methods. Therefore, we are confident in our results. Interestingly, Ritter et al. (2013) analysed P. teleius individuals from four populations in Poland - Wólka near Warsaw, Kosyń near Włodawa, Wiesiółka near Zawiercie and Widacz near Krosno. However, all individuals from these populations were also free from Wolbachia infection.

Our study was performed on populations located between Wólka and Zawiercie (Ritter et al. 2013), providing information about Wolbachia infection in another part of the Polish range of $P$. teleius. In contrast, a recent genetic study conducted on $P$. teleius revealed the occurrence of Wolbachia infection (lineage B) in Mongolian, Russian (Altai region), Belarusian and French $P$. teleius populations (Ritter et al. 2013), as well as (lineage A and B) in Hungary and Romania (Bereczki et al. 2015). In total, 13\% of screened individuals were infected within the investigated range of $P$. teleius occurrence in Ritter et al. (2013) and 14\% of examined individuals were reported to be infected in the Carpathian Basin (Bereczki et al. 2015).

Other butterfly species from the Phengaris clade have also shown differential Wolbachia infection. So far, Wolbachia has been found in $P$. nausithous (Bergsträsser, 1779) populations in Kazakhstan, Russia (Volgograd region), Slovakia and Czechia (Wolbachia super-group B; Ritter et al. 2013) as well as in Hungary and Romania (super-group A and B, Bereczki et al. 2015). Wolbachia infection has also been documented in $P$. alcon (Denis \& Schiffermüller, 1775) from Lithuania, Poland, Austria, Hungary and Romania (Wolbachia supergroup B, Sielezniew et al. 2012, Bereczki et al. 2015) and in $P$. arion (Linnaeus, 1758) from Poland, Italy, Hungary and Romania (Wolbachia supergroup A, Patricelli et al. 2013, Bereczki et al. 2015).

Our study showed that populations of $P$. teleius from southern Poland are attacked by an unidentified species of ectoparasitoid wasps. To our knowledge, this is the first observation of ectoparasitoid larvae feeding on caterpillars of Phengaris butterflies. At the same time, we failed 

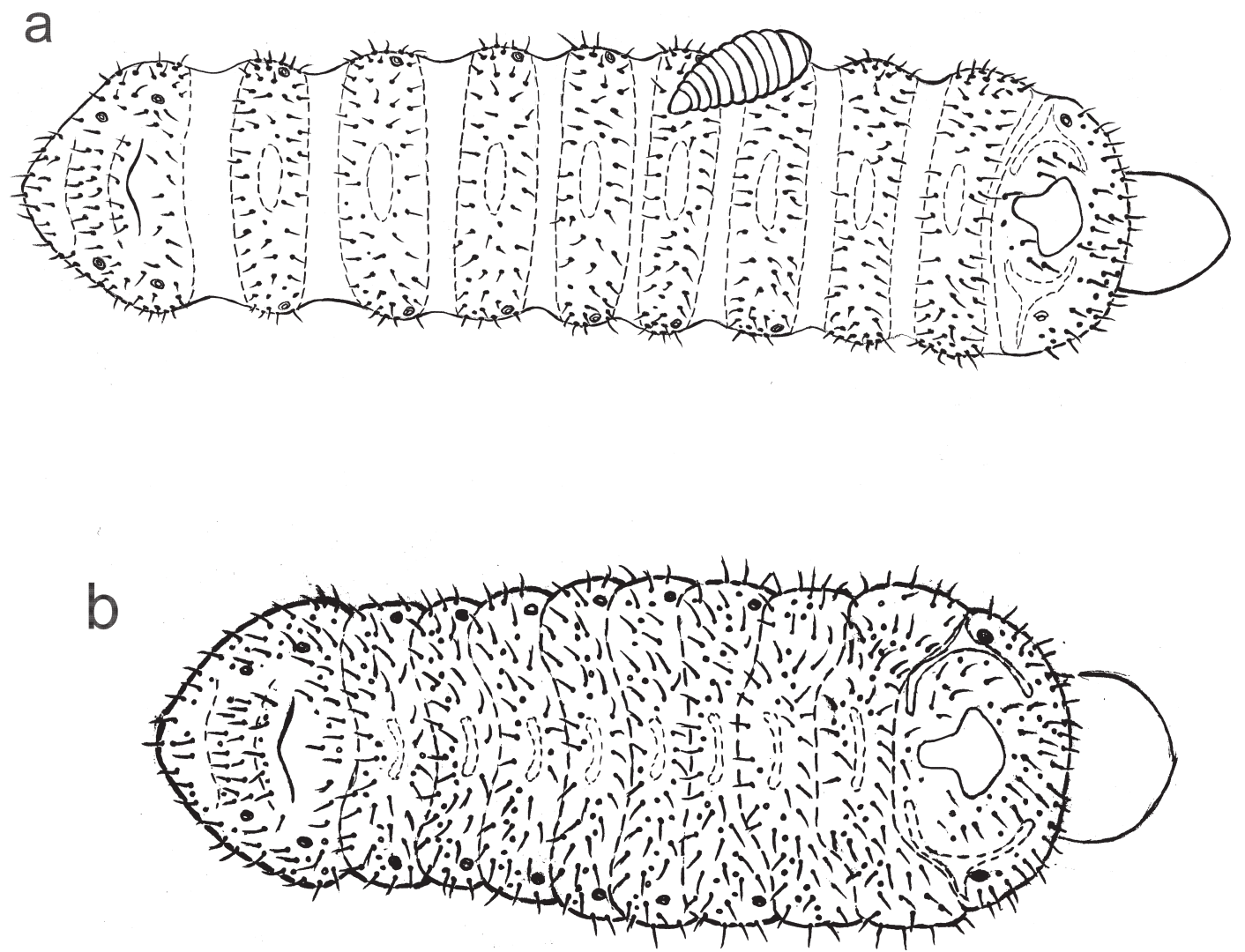

Fig. 2. Sketches of a $3^{\text {rd }}$ instar caterpillar of Phengaris teleius. - a. A paralyzed caterpillar infested by an ectoparasitoid larva. - b. An uninfested caterpillar.

to find the larvae of any endoparasitic wasps in $P$. teleius caterpillars from the same region of southern Poland. The latter finding is concordant with that of Anton et al. (2007a), who studied two populations of $P$. teleius (similarly, by dissecting $P$. teleius caterpillars feeding on plants; Anton, unpublished data) in the Upper Rhine Valley, southwestern Germany.

In general, various endoparasitic Neotypus (Ichneumonidae) species attack the predatory myrmecophilous species of Phengaris (P. teleius, $P$. nausithous and $P$. arion). In particular, in Hungary, larvae of the parasitoid wasp, N. melanocephalus Gmelin, 1790 (= N. pusillus Gregor, 1940) have been found in a P. teleius pupa, originating from Myrmica nests (Tartally 2005). This suggests that $N$. melanocephalus is the parasitoid of $P$. teleius in the Carpathian Basin, but its frequency is very low (only one pupa with a parasitoid larva was detected among eight sites of $P$. teleius in the Carpathian Basin, Tartally 2005).
Probably, $N$. melanocephalus is a specialist parasitoid of $P$. nausithous, the sister species of $P$. teleius, and it is recorded from Poland (Stankiewicz et al. 2004) and southwestern Germany (Anton et al. 2007a). Therefore, the observations of $N$. melanocephalus attacking $P$. teleius caterpillars might be based on accidental events. In turn, N. coreensis Uchida, 1930 has been shown to attack the predatory $P$. arion (Sielezniew et al. 2010).

In contrast, Ichneumon sp. attacks $P$. alcon, a Phengaris species with the "cuckoo" lifestyle (Thomas \& Elmes 1993, Sielezniew \& Stankiewicz 2004, Stankiewicz et al. 2004, Tartally 2005, 2008, Tartally et al. 2013, 2014, Timu et al. 2013). So far, there is one known case of predatory P. teleius getting parasitized by Ichneumon sp. (Tartally 2008). Ichneumon sp. has numerous adaptations to infiltrate Myrmica colonies and to find and oviposit into Phengaris larvae. Therefore, Phengaris cuckoo species are attacked by 
parasitoids only within Myrmica ant colonies (Thomas \& Elmes 1993, Witek et al. 2014).

The presence and diversity of parasites within an ecosystem is a sign of its health (Hudson et al. 2006). So, what is the implication of the scarce number of parasites attacking a given species in local populations? The potential reasons of very low frequency of parasites in the studied $P$. teleius butterfly (including Wolbachia) may be in density-dependent effects occurring in host populations across the study region (Cronin 2004, Hancock et al. 2016), but also in biotic and abiotic factors, such as natural enemies of parasites, or microclimatic conditions (Ram et al. 2008, Heard et al. 2015).

The host population turnover and decrease in host densities may have a negative effect on the persistence of parasitoid populations, as well (e.g. Cronin 2004). Populations of $P$. teleius located in our study area have been described as stable and weakly influenced by weather conditions (Nowicki et al. 2005, 2009), as well as resistant to natural catastrophes (i.e. flood and fire, KajzerBonk et al. 2013, Nowicki et al. 2014).

However, during the two years of our study, we witnessed the disappearance of several subpopulations of $P$. teleius, most likely due to succession and a lack of proper habitat management within respective habitat patches (Batáry et al. 2007, Dierks \& Fischer 2009, van Swaay et al. 2012). In the context of frequent subpopulation turnovers, like those observed for P. teleius in southern Poland, the conditions for the persistence of the populations of parasites may not be met. Otherwise, the lack of Wolbachia infection among inspected $P$. teleius caterpillars may be due to other factors than frequent population turnovers.

In fact, $P$. arion and $P$. alcon have infestation levels of $100 \%$ (e.g. Particelli et al. 2013, Bereczki et al. 2015) even though their population parameters are similar to $P$. teleius. Therefore, the potential mechanisms that cause low levels of Wolbachia infection in P. teleius remain unknown. To fully understand the factors that determine parasitoid occurrence and Wolbachia infection in P. teleius populations, a large scale, longterm study is needed, which would take into account habitat changes and the abundance dynamics of butterflies in local populations.
Acknowledgements. Specimens of P. teleius caterpillars were collected with permission of the General Directorate for Environmental Protection in Poland (DOP-oz. 6401.01.52.2013.JRO). The study was financially supported by the Polish National Science Centre via a postdoctoral fellowship (DEC-2012/04/S/NZ8/00215) and partly by statutory funds of the Institute of Nature Conservation of the Polish Academy of Sciences. We thank anonymous reviewers for useful commentaries that helped to improve the manuscript.

\section{References}

Anton, C., Musche, M. \& Settele, J. 2007a: Spatial patterns of host exploitation in a larval parasitoid of the predatory dusky large blue Maculinea nausithous. - Basic and Applied Ecology 8: 66-74. doi: https://doi.org/ 10.1016/j.baae.2006.03.006

Anton, C., Zeisset, I., Musche, M., Durka, W., Boomsma, J. J. \& Settele, J. 2007b: Population structure of a large blue butterfly and its specialist parasitoid in a fragmented landscape. - Molecular Ecology 16: 3828-3838. doi: $\quad$ https://doi.org/10.1111/j.1365-294X.2007. 03441.x

Batáry, P., Örvössy, N., Kőrösi, Á., Vályinagy, M. \& Peregovits, L. 2007: Microhabitat preferences of Maculinea teleius (Lepidoptera: Lycaenidae) in a mosaic landscape. - European Journal of Entomology 104: 731-736. doi: https://doi.org/10.14411/eje.2007.093

Bereczki, J., Rácz, R., Varga, Z. \& Tóth, J. P. 2015: Controversial patterns of Wolbachia infestation in the social parasitic Maculinea butterflies (Lepidoptera: Lycaenidae). - Organisms Diversity \& Evolution 15: 591-607. doi: https://doi.org/10.1007/s13127-0150217-7

Burks, R. A. 2003: Key to the Nearctic genera of Eulophidae, subfamilies Entedoninae, Euderinae and Eulophinae (Hymenoptera: Chalcidoidea). — World Wide Web electronic publication. URL http//cache.ucr.edu/\%7Eheraty/Eulophidae/ (Site visited on 10 October 2017.)

Cronin, J. T. 2004: Host-parasitoid extinction and colonization in a fragmented prairie landscape. - Oecologia 139: 503-514. doi: https://doi.org/10.1007/s00442004-1549-8

Dierks, A. \& Fischer, K. 2009: Habitat requirements and niche selection of Maculinea nausithous and M. teleius (Lepidoptera: Lycaenidae) within a large sympatric metapopulation. - Biodiversity and Conservation 18: 3663-3676. doi: https://doi.org/10.1007/s10531009-9670-y

Dobson, A. P. \& Hudson, P. J. 1986: Parasites, disease and the structure of ecological communities. - Trends in Ecology and Evolution 1: 11-15. doi: https://doi.org/ 10.1016/0169-5347(86)90060-1

Godfray, H. \& Charles, J. 1994: Parasitoids: Behavioral and Evolutionary Ecology. — Princeton University Press, Princeton. 473 pp. 
Goulet, H. \& Huber, J. T. 1993: Hymenoptera of the world: an identification guide to families. - Ottawa, Ont, Centre for Land and Biological Resources Research.

Hamm, C. A., Handley, C. A., Pike, A., Forister, M. L. Fordyce, J. A. \& Nice, C. C. 2014: Wolbachia infection and Lepidoptera of conservation concern. Journal of Insect Science 14: 6. doi: https://doi.org/ 10.1093/jis/14.1.6

Hancock, P. A., White, V. L., Ritchie, S. A., Hoffmann, A. A. \& Godfray, H. C. J. 2016: Predicting Wolbachia invasion dynamics in Aedes aegypti populations using models of density-dependent demographic traits. BMC Biology 14: 96. doi: https://doi.org/10.1186/ s12915-016-0319-5

Heard, G. W., Thomas, C. D., Hodgson, J. A., Scroggie, M. P., Ramsey, D. S. \& Clemann, N. 2015: Refugia and connectivity sustain amphibian metapopulations afflicted by disease. — Ecology Letters 18: 853-863. doi: https://doi.org/10.1111/ele.12463

Hinz, R. 1983: The biology of the European species of the genus Ichneumon and related species (Hymenoptera: Ichneumonidae). - Contribution of the American Entomological Institute 20: 151-152.

Hudson, P. J., Dobson, A. P. \& Lafferty, K. D. 2006: Is a healthy ecosystem one that is rich in parasites? Trends in Ecology and Evolution 21: 381-385. doi: https://doi.org/10.1016/j.tree.2006.04.007

Kajzer-Bonk, J., Nowicki, P., Bonk, M., Skórka, P., Witek, M. \& Woyciechowski, M. 2013: Local populations of endangered Maculinea (Phengaris) butterflies are flood resistant. — Journal of Insect Conservation 17: 1105-1112. doi: https://doi.org/10.1007/s10841013-9591-7

McCallum, H. \& Dobson, A. 1995: Detecting disease and parasite threats to endangered species and ecosystems. - Trends in Ecology and Evolution 10: 190-194. doi: https://doi.org/10.1016/S0169-5347(00)89050-3

Nice, C. C., Gompert, Z., Forister, M. L. \& Fordyce, J. A. 2009: An unseen foe in arthropod conservation efforts: The case of Wolbachia infections in the Karner blue butterfly. - Biological Conservation 142: $3137-$ 3146. doi: https://doi.org/10.1016/j.biocon.2009.08. 020

Nowicki, P., Bonelli, S., Barbero, F. \& Balletto, E. 2009: Relative importance of density-dependent regulation and environmental stochasticity for butterfly population dynamics. - Oecologia 161: 227-239 doi: https://doi.org/10.1007/s00442-009-1373-2

Nowicki, P., Marczyk, J. \& Kajzer-Bonk, J. 2014: Metapopulations of endangered Maculinea butterflies are resilient to large-scale fire. - Ecohydrology 8: 398405. doi: https://doi.org/10.1002/eco.1484

Nowicki, P., Witek, M., Skórka, P., Settele, J. \& Woyciechowski, M. 2005: Population ecology of the endangered butterflies Maculinea teleius and M. nausithous, and its implications for conservation. - Population Ecology 47: 193-202. doi: https://doi.org/10.1007/ s10144-005-0222-3

Patricelli, D., Sielezniew, M., Ponikwicka-Tyszko, D., Ratkiewicz, M., Bonelli, S., Barbero, F., Witek, M.,
Buś, M. M., Rutkowski, R. \& Balletto, E. 2013: Contrasting genetic structure of rear edge and continuous range populations of a parasitic butterfly infected by Wolbachia. - BMC Evolutionary Biology 13: 14. doi: https://doi.org/10.1186/1471-2148-13-14

Quicke, D. L. J. 1997: Parasitic wasps. — Chapman \& Hall Ltd., London. 470 pp.

Ram, K., Preisser, E. L., Gruner, D. S. \& Strong, D. R. 2008: Metapopulation dynamics override local limits on long-term parasite persistence. - Ecology 89: 3290-3297. doi: https://doi.org/10.1890/08-0228.1

Ritter, S., Michalski, S. G., Settele, J., Wiemers, M., Fric, Z. F., Sielezniew, M., Šašić, M., Rozier, Y.\& Durka, W. 2013: Wolbachia infections mimic cryptic speciation in two parasitic butterfly species, Phengaris teleius and $P$. nausithous (Lepidoptera: Lycaenidae). PLoS ONE 8(11): e78107. doi: https://doi.org/ 10.1371/journal.pone.0078107

Shaw, M. R. \& Hochberg, M. E. 2002: The neglect of parasitic hymenoptera in insect conservation strategies: the British fauna as a prime example. - Journal of Insect Conservation 5: 253-263. doi: https://doi.org/ 10.1023/A:1013393229923

Sielezniew, M., Rutkowski, R., Ponikwicka-Tyszko, D., Ratkiewicz, M., Dziekanska, I. \& Švitra, G. 2012: Differences in genetic variability between two ecotypes of the endangered myrmecophilous butterfly Phengaris (= Maculinea) alcon - the setting of conservation priorities. - Insect Conservation and Diversity 5: 223-236.

Sielezniew, M. \& Stankiewicz, A. M. 2004: Simultaneous exploitation of Myrmica vandeli and M. scabrinodis (Hymenoptera: Formicidae) colonies by the endangered myrmecophilous butterfly Maculinea alcon (Lepidoptera: Lycaenidae). — European Journal of Entomology 101: 693-696. doi: https://doi.org/ 10.14411/ eje. 2004.091

Sielezniew, M., Włostowski, M. \& Dziekańska, I. 2010: Myrmica schencki (Hymenoptera: Formicidae) as the primary host of Phengaris (Maculinea) arion (Lepidoptera: Lycaenidae) at heathlands in eastern Poland. — Sociobiology 55: 1-12.

Stankiewicz, A. M., Sielezniew, M. \& Sawoniewicz, J. 2004: Neotypus pusillus Gregor, 1940 (Hymenoptera, Ichneumonidae) endoparasite of Maculinea nausithous (Bergsträsser, 1779) (Lepidoptera, Lycaenidae): new data on distribution in Poland with remarks on its biology. - Fragmenta Faunistica 47: 115-120.

Śliwińska, E. B., Nowicki, P., Nash, D. R., Witek, M., Settele, J. \& Woyciechowski, M. 2006: Morphology of caterpillars and pupae of European Maculinea species (Lepidoptera: Lycaenidae) with an identification table. - Entomologica Fennica 17: 351-358.

Tartally, A. 2005: Neotypus melanocephalus (Hymenoptera: Ichneumonidae): first record of a parasitoid wasp attacking Maculinea teleius (Lycaenidae). — Nota Lepidopterologica 28: 21-23.

Tartally, A. 2008: Myrmecophily of Maculinea butterflies in the Carpathian Basin (Lepidoptera: Lycaenidae). 
PhD thesis. - University of Debrecen, Debrecen. 25 pp.

Tartally, A., Koschuh, A. \& Varga, Z. 2014: The re-discovered Maculinea rebeli (Hirschke, 1904): Host ant usage, parasitoid and initial food plant around the type locality with taxonomical aspects (Lepidoptera, Lycaenidae). — ZooKeys 406: 25-40. doi: https://doi.org/ 10.3897/zookeys.406.7124

Tartally, A., Rodrigues, M. C., Brakels, P. \& Arnaldo, P. S. 2013: Myrmica aloba (Hymenoptera: Formicidae) hosts isolated populations of a hoverfly, a butterfly and an ichneumon species in NE-Portugal. - Journal of Insect Conservation 17: 851-855. doi: https://doi.org/ 10.1007/s10841-013-9575-7

Thomas, J. A. 1984: The behaviour and habitat requirements of Maculinea nausithous (the dusky large blue butterfly) and $M$. teleius (the scarce large blue) in France. - Biological Conservation 28: 325-347. doi: https://doi.org/10.1016/0006-3207(84)90040-5

Thomas, J. A. 1995: The ecology and conservation of $M a-$ culinea arion and other European species of the large blue butterfly. — In: Pullin A. S. (ed.), Ecology and Conservation of Butterflies: 180-197. Chapman \& Hall, London. 363 pp.

Thomas, J. A. \& Elmes, W. 1993: Specialised searching and the hostile use of allomones by a parasitoid whose host, the butterfly Maculinea rebeli inhabits ant nests. — Animal Behavior 45: 593-602. doi: https://doi.org/ 10.1006/anbe.1993.1069

Thomas, J. A. \& Settele, J. 2004: Butterfly mimics of ants. - Nature 432: 283-284. https://doi.org/10.1038/ 432283a

Timu, N., Constantineanu, R. \& Rákosy, L. 2013: Ichneumon balteatus (Hymenoptera: Ichneumonidae) - a new parasitoid species of Maculinea alcon butterflies (Lepidoptera: Lycaenidae). — Entomologica Romanica 18: 31-35.

Van Lenteren, J.C. 2000: Success in biological control of arthropods by augmentation of natural enemies. - In: Gurr G. \& Wratten S. (eds), Biological Control: Measures of Success: 77-104. Kluwer Academic Publishers, Dordrecht. 428 pp. doi: https://doi.org/ 10.1007/978-94-011-4014-0_3

Van Lenteren, J. C. \& Woets, J. 1988: Biological and integrated pest control in greenhouses. - Annual Review of Entomology 33: 239. doi: https://doi.org/10.1146/ annurev.en.33.010188.001323

van Swaay, C., Collins, S., Dušej, G., Maes, D., Munguira, M.L., Rakosy, L., Ryrholm, N., Šašić, M., Settele, J., Thomas, J. A., Verovnik, R., Verstrael, T., Warren, M., Wiemers, M. \& Wynhoff, I. 2012: Dos and Don'ts for butterflies of the Habitats Directive of the European Union. - Nature Conservation 1: 73-153. doi: https://doi.org/10.3897/natureconservation.1.2786

van Swaay, C. A. M. \& Warren, M. S. 1999: Red data book of European butterflies (Rhopalocera). — Nature and Environment 99: 129-134.

Werren, J. H., Baldo, L. \& Clark, M. E. 2008: Wolbachia: master manipulators of invertebrate biology. - Nature Reviews Microbiology 6: 741-751. doi: https://doi.org/10.1038/nrmicro1969

Werren, J. H. \& Windsor, D. M. 2000: Wolbachia infection frequency in insects: evidence of a global equilibrium? - Proceedings of the Royal Society of London B 267: 1277-1285. doi: https://doi.org/10.1098/ rspb.2000.1139

Witek, M., Barbero, F. \& Markó, B. 2014: Myrmica ants host highly diverse parasitic communities: from social parasites to microbes. — Insectes Sociaux 61: 307323. doi: https://doi.org/10.1007/s00040-014-0362-6

Witek, M., Śliwińska, E. B., Skórka, P., Nowicki, P. \& Woyciechowski, M. 2006: Polymorphic growth in larvae of Maculinea butterflies, as an example of biennialism in myrmecophilous insects. - Oecologia 148: 729-733. doi: https://doi.org/10.1007/s00442-0060404-5 